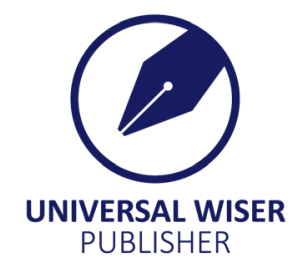

\title{
Transcription of Escherichia Coli O157:H7 Key Virulence Genes During Growth in Liquid Medium and Rocket (Eruca Sativa) at 4 and $10^{\circ} \mathrm{C}$
}

\author{
A. Hadjilouka, O. Panagiotopoulou, S. Paramithiotis", E.H. Drosinos \\ Laboratory of Food Quality Control and Hygiene, Department of Food Science and Human Nutrition, Agricultural University of Athens, \\ Iera Odos 75, 11855 Athens, Greece \\ E-mail: sdp@aua.gr
}

\begin{abstract}
The aim of the present study was to comparatively assess the transcription of key virulence genes, during growth of an Escherichia coli O157:H7 isolate in liquid medium and rocket (Eruca sativa) at different temperatures and time. For that purpose, rocket leaves and BHI broth were inoculated with $7.5 \log \mathrm{CFU} / \mathrm{g}$ or $\mathrm{CFU} / \mathrm{mL}$, respectively, and incubated at 4 and $10^{\circ} \mathrm{C}$. Sampling took place upon inoculation and after 0.5, 6 and $24 \mathrm{~h}$ of incubation; the RNA was stabilized and the transcription of stxl, stx2, eae, ehxA and etpD was assessed by RT-qPCR. Downregulation of stxl and ehxA during growth on rocket surface at $4^{\circ} \mathrm{C}$, upregulation of stx2 and eae during growth on rocket surface at both 4 and $10^{\circ} \mathrm{C}$ and the upregulation of $e t p D$ and $e h x A$ during growth on rocket surface at 4 and $10^{\circ} \mathrm{C}$, respectively, were observed. In addition, increase of incubation temperature, i.e. from 4 to $10^{\circ} \mathrm{C}$ resulted in upregulation of stx 1 and downregulation of stx 2 and eae. These results suggest that through differential regulation of genes encoding for virulence factors, the virulence potential of E. coli $\mathrm{O} 157: \mathrm{H7}$ may be altered when it resides on the surface of rocket, at least for short time and at temperature relevant to its storage. However, further research is still necessary in order to improve our understanding of the physiology of this foodborne pathogen and the responses during exposure to food-related stresses.
\end{abstract}

Keywords: Escherichia coli, rocket, stx1, stx2, eae, ehxA, etpD

\section{Introduction}

Escherichia coli is an important foodborne pathogen implicated in several outbreaks every year. A total of 20-30\% of the $E$. coli infections has fresh produce as etiological agent ${ }^{[1]}$. In addition, shiga toxin-producing $E$. coli (STEC) was the third most common etiological agent of foodborne disease outbreaks reported in the USA in 2011 and 2012, second in 2013 and fourth in $2014^{[2-5]}$, with O157 serogroup being held responsible for more than half of the outbreaks. The most known O157:H7 outbreaks include the 2006 multistate outbreak associated with the consumption of fresh spinach ${ }^{[6]}$ and the 1996 Japan outbreak linked to the consumption of white (daikon) radish sprouts ${ }^{[7]}$.

STEC pathogenicity and virulence factors have been adequately studied and reviewed ${ }^{[8-10]}$. More specifically, regulation of the genes encoding for the Shiga toxins (stxl and stx2), intimin (eae) and enterohemolysin (ehxA) has attracted attention due to their increased importance. In addition, their transcription in actual food matrices has also been assessed. Carey et al. ${ }^{[1]]}$ assessed $f l i C$, sodB, eae, stx $1 A$, stx $2 A$ and $r p o S$ transcription during growth on romaine lettuce at 4 and $15^{\circ} \mathrm{C}$ for up to 9 days. Sharma et al. ${ }^{[12]}$ studied the effect of modified atmosphere packaging on iha, $r f b E$, eae, ehxA and $s t x 2$ transcription during growth on shredded lettuce stored at 4 and $15^{\circ} \mathrm{C}$ for up to 10 days. Mahmoudzadeh et al. ${ }^{[13]}$ studied the transcription of stx $1 A$ and $s t x 2 A$ during growth on ground beef stored at $4^{\circ} \mathrm{C}$ for up to 7 days. Finally, Van der Linden et al. ${ }^{[14]}$ used a microarray-based screening to assess the transcriptomic response during preharvest survival on butterhead lettuce.

Rocket (Diplotaxis tenuifolia (L.) DC., wild rocket; Eruca sativa Mill., cultivated rocket) is among the most appreciated vegetables and therefore its postharvest physiology, phytonutrient content, microbiological quality and shelf life have been extensively studied ${ }^{[15-21]}$. Rocket has been implicated as the food vehicle of two outbreaks, 2001 with Cyclospora cayetanensis as confirmed etiological agent and in 2016 with STEC as the suspected agent (data retrieved from www.fda.gov/Safety/Recalls/ArchiveRecalls/default.htm). However, the transcriptional response of STEC during growth on rocket salad has not yet been studied.

Copyright (C2020 S. Paramithiotis, et al.

DOI: https://doi.org/10.37256/amtt.122020493

This is an open-access article distributed under a CC BY license

(Creative Commons Attribution 4.0 International License)

https://creativecommons.org/licenses/by/4.0/ 
The aim of the present study was to assess comparatively the transcription of five key virulence genes, namely stx 1 , stx2, eae, ehxA and etpD during growth of E. coli $\mathrm{O} 157: \mathrm{H} 7$ in liquid medium and on rocket surface stored at 4 and $10^{\circ} \mathrm{C}$.

\section{Materials and methods}

\subsection{Bacterial strains and sample preparation}

Escherichia coli O157:H7 strain LQC 15263, previously isolated from a cucumber sample was used throughout this study. Long-term storage took place at $-20^{\circ} \mathrm{C}$ in nutrient broth supplemented with $50 \%$ glycerol. Before experimental use, the strain was grown twice in Brain Heart Infusion broth (Biolife, Milan, Italy) at $37^{\circ} \mathrm{C}$ for $24 \mathrm{~h}$. For inoculum preparation, 10 test tubes containing $10 \mathrm{~mL}$ BHI broth were inoculated with the E. coli O157:H7 culture and incubated overnight at $37^{\circ} \mathrm{C}$, resulting in a population of $8.5 \log \mathrm{CFU} / \mathrm{mL}$. All test tubes were centrifuged $\left(12,000 \times \mathrm{g} ; 10 \mathrm{~min} ; 4^{\circ} \mathrm{C}\right)$, the biomass was washed twice with sterile saline, pooled and resuspended in $10 \mathrm{~mL}$ of the same diluent and used to inoculate BHI broth and rocket samples at $7.5 \log \mathrm{CFU} / \mathrm{mL}$ or CFU/g, respectively. More accurately, $50 \mathrm{~g}$ of rocket (Eruca sativa) were placed in sterile containers (of approx. $500 \mathrm{~mL}$ volume) and sprayed with $0.5 \mathrm{~mL}$ of the diluted pathogen population to obtain the desired final population. In the case of BHI broth, $50 \mu \mathrm{L}$ of the diluted pathogen were used to inoculate test tubes containing $5 \mathrm{~mL}$ of BHI broth. Before inoculation, all respective materials were placed overnight at the intended incubation temperature for temperature equilibration. Incubation took place at 4 and $10^{\circ} \mathrm{C}$.

\subsection{Microbiological analyses}

E. coli O157:H7 enumeration was performed by spreading serial dilutions on the surface of E. coli O157:H7 agar (Merck, Darmstadt, Germany) and BHI agar. The former was used to enumerate the population of the pathogen and the latter to exclude the presence of contaminating bacteria, especially in the case of rocket inoculation. Incubation took place at $35^{\circ} \mathrm{C}$ for $24 \mathrm{~h}$.

\subsection{In vitro and in situ gene transcription assay}

Sampling was performed immediately upon inoculation (time $0 \mathrm{~h}$ ) and after $0.5,6$ and $24 \mathrm{~h}$ of incubation. In the case of broth samples, $5 \mathrm{~mL}$ were centrifuged $(12,000 \mathrm{x} g ; 1 \mathrm{~min}$, sample temperature), the supernatant was discarded and the pellet was mixed with $200 \mu \mathrm{L}$ of RNAlater ${ }^{\circledR}$ solution (Ambion, Whaltham, MA, USA). In the case of rocket samples, $10 \mathrm{~g}$ were first homogenized using a Stomacher apparatus (30 s at $230 \mathrm{RPM}$ ) (Seward, London, UK) with $90 \mathrm{~mL}$ of sterile Ringer solution (LABM, Lancashire, UK) equilibrated at sample temperature. Then, $5 \mathrm{~mL}$ of the homogenate was transferred in sterile falcon tubes, centrifuged and the RNA was stabilized as above. The experiment was performed in triplicate. RNA extraction was performed with the NucleoSpin ${ }^{\circledR}$ RNA kit (Macherey-Nagel, Duren, Germany) and cDNA synthesis with the PrimeScript ${ }^{\mathrm{TM}}$ RT reagent kit (Takara, Shiga, Japan) according to the instructions of the manufacturer. Real-Time qPCR was performed with the KAPA SYBR qPCR Kit Master Mix (2X) for ABI Prism (KapaBiosystems, Boston, MA, USA). Primers and PCR conditions are presented in Table 1. cysG, gap, rrs A and ihfB were selected as housekeeping genes on the basis of the available literature while $\operatorname{stx} 1$, stx2, eae, ehxA and etpD due to their significance in virulence potential of E. coli O157:H7. Approximately $0.5 \mu \mathrm{g}$ RNA of each sample was used for two RT reactions and the resulting cDNA was used for the assessment of the transcription of the genes under study. 
Table 1. Primer sequences and respective amplicon sizes used for the in vitro and in situ gene transcription assay

\begin{tabular}{|c|c|c|c|c|}
\hline Genes & & sequence & amplicon size (bp) & PCR efficiency \\
\hline \multicolumn{5}{|c|}{ Housekeeping } \\
\hline \multirow[t]{2}{*}{ cys $G$} & cysG_f ${ }^{[22]}$ & TTGTCGGCGGTGGTGATGTC & 105 & 2.00 \\
\hline & cysG_r ${ }^{[22]}$ & ATGCGGTGAACTGTGGAATAAACG & & \\
\hline \multirow[t]{2}{*}{ gap } & gap_f ${ }^{[23]}$ & AGGTCTGATGACCACCGTTCA & 65 & 1.97 \\
\hline & gap_r ${ }^{[23]}$ & TGTGAGACGGGCCATCAAC & & \\
\hline \multirow[t]{2}{*}{$\operatorname{rrs} A$} & rrsA_f ${ }^{[24]}$ & CTCTTGCCATCGGATGTGCCCA & 105 & 1.89 \\
\hline & rrsA_r ${ }^{[24]}$ & CCAGTGTGGCTGGTCATCCTCTCA & & \\
\hline \multirow[t]{2}{*}{$\operatorname{ihfB}$} & $\operatorname{ihfB} \_f^{[25]}$ & GCGGTTTCGGCAGTTTCT & 124 & 2.01 \\
\hline & ihfB_r ${ }^{[25]}$ & CGCAGTTCTTTACCAGGTTT & & \\
\hline \multicolumn{5}{|c|}{ Virulence associated } \\
\hline \multirow[t]{2}{*}{ stx 1} & stx $1 \_f[26]$ & GGATAATTTGTTTGCAGTTGATGTC & 107 & 1.95 \\
\hline & stx1_r ${ }^{[26]}$ & CAAATCCTGTCACATATAAATTATTTCGT & & \\
\hline \multirow[t]{2}{*}{ stx 2} & $\operatorname{stx} 2 \_f{ }^{[26]}$ & GGGCAGTTATTTTGCTGTGGA & 130 & 1.97 \\
\hline & $\operatorname{stx} 2 \mathrm{r}^{[26]}$ & GAAAGTATTTGTTGCCGTATTAACGA & & \\
\hline \multirow[t]{2}{*}{ eae } & eae_f $[26]$ & CATTGATCAGGATTTTTCTGGTGATA & 102 & 2.02 \\
\hline & eae_r ${ }^{[26]}$ & CTCATGCGGAAATAGCCGTTA & & \\
\hline \multirow[t]{2}{*}{$e h x A$} & $\operatorname{ehx} \bar{A} \_f[26]$ & CGTTAAGGAACAGGAGGTGTCAGTA & 142 & 1.98 \\
\hline & ehxA_r- ${ }^{[26]}$ & ATCATGTTTTCCGCCAATGAG & & \\
\hline \multirow[t]{2}{*}{$\operatorname{etp} D$} & etp $\bar{D} \_f$ & CGTCAGGAGGATGTTCAC & 84 & 2.04 \\
\hline & etpD_r & ACCTGTCAGGACTTCCACTA & & \\
\hline
\end{tabular}

Primer concentration was $1 \mathrm{uM}$. Thermocycling conditions were $95^{\circ} \mathrm{C}$ for $20 \mathrm{sec}$ and $40 \mathrm{x}\left(95^{\circ} \mathrm{C}\right.$ for $10 \mathrm{sec}, 60^{\circ} \mathrm{C}$ for $30 \mathrm{sec}, 72^{\circ} \mathrm{C}$ for $\left.30 \mathrm{sec}\right)$.

Melting curve analysis : $95^{\circ} \mathrm{C}$ for 15 sec then $60^{\circ} \mathrm{C}$ for $1 \mathrm{~min}$ and raise to $95^{\circ} \mathrm{C}$ at $0.3^{\circ} \mathrm{C} / \mathrm{sec}$.

\subsection{Statistical analysis}

Pretreatment and data analysis was performed according to Hadjilouka et al. ${ }^{[27]}$. Relative gene transcription during growth on rocket was assessed by comparison to the respective during growth in BHI broth under identical conditions. Regulation of the gene transcription was only considered when the $\log _{2}$ value of the fold change $\left(\log _{2} \mathrm{FC}\right)$ was above 1 and below -1 , for up- and down- regulation, respectively, assessed through one-sample $\mathrm{t}$-test $(p<0.05)$. One-way analysis of variance (ANOVA) was used to statistically evaluate the differences between the population dynamics of $E$. coli O157:H7 during growth.

\section{Results-discussion}

E. coli $\mathrm{O} 157: \mathrm{H} 7$ population presented statistically significant increase only in $\mathrm{BHI}$ broth after $24 \mathrm{~h}$ incubation at $10^{\circ} \mathrm{C}$; in all other cases it remained at the inoculation level (Table 2).

Table 2. E. coli $\mathrm{O157: \textrm {H } 7}$ population dynamics $\left(\log \mathrm{CFU} \mathrm{\textrm {mL } ^ { - 1 }}\right.$ or $\left.^{-1}\right)$ in $\mathrm{BHI}$ broth and rocket during incubation at 4 and $10^{\circ} \mathrm{C}$

\begin{tabular}{cccc}
\hline \multirow{2}{*}{ Temperature $\left({ }^{\circ} \mathrm{C}\right)$} & Time $(\mathrm{h})$ & \multicolumn{2}{c}{ Growth substrate } \\
\cline { 3 - 4 } & 0 & $7.78(0.35)^{\mathrm{a}}$ & rocket \\
\hline $4^{\circ} \mathrm{C}$ & 0.5 & $8.15(0.13)^{\mathrm{a}}$ & $7.51(0.42)^{\mathrm{a}}$ \\
& 6.0 & $8.08(0.20)^{\mathrm{a}}$ & $7.74(0.46)^{\mathrm{a}}$ \\
& 24.0 & $7.83(0.05)^{\mathrm{a}}$ & $7.97(0.38)^{\mathrm{a}}$ \\
$10^{\circ} \mathrm{C}$ & 0 & $7.78(0.43)^{\mathrm{a}}$ & $7.52(0.42)^{\mathrm{a}}$ \\
& 0.5 & $7.59(0.19)^{\mathrm{a}}$ & $7.92(0.54)^{\mathrm{a}}$ \\
& 6.0 & $8.08(0.32)^{\mathrm{a}}$ & $7.39(0.35)^{\mathrm{a}}$ \\
& 24.0 & $8.75(0.17)^{\mathrm{b}}$ & $7.46(0.15)^{\mathrm{a}}$ \\
\hline
\end{tabular}

Standard deviation is given in parenthesis.

Within a column, for each temperature, different superscript letters denote significant differences $(a<0.05)$.

In Table 1, the PCR efficiency values of the primers, used in the present study to assess the transcription of reference and target genes, as estimated from the slope of the respective linear regression plot is presented. The results showed that the best gene for normalization, producing the lower inter- (between groups) and intra-variation (within each group), was cys $G$.

In Figure 1. the effect of time, substrate and incubation temperature on the transcription of stxl, stx2, eae, ehxA and etpD, are shown. Studying gene transcription on rocket compared to BHI broth revealed that transcription of all genes assessed was affected. More accurately, growth on rocket surface at $4^{\circ} \mathrm{C}$ resulted in downregulation of stxl and ehxA after $0.5 \mathrm{~h}$ growth and upregulation of $s t x 2$, eae and etpD after $6 \mathrm{~h}$ growth. Similarly, downregulation of $s t x 1$ was also observed 
after $6 \mathrm{~h}$ growth on rocket surface at $10^{\circ} \mathrm{C}$, while upregulation of stx 2 after $0.5 \mathrm{~h}$, eae immediately upon inoculation and after $0.5 \mathrm{~h}$ and $e h x A$ immediately upon inoculation and after $6.0 \mathrm{~h}$ growth, were also noticed. Regarding the effect of temperature, relative quantification of gene transcription revealed that stx 1 was upregulated after $6 \mathrm{~h}$ growth at $10^{\circ} \mathrm{C}$ in $\mathrm{BHI}$ broth and rocket surface, when compared to growth at $4^{\circ} \mathrm{C}$. On the contrary, downregulation of stx 2 and eae were noted after 0.5 and $6.0 \mathrm{~h}$ growth at $10^{\circ} \mathrm{C}$ in $\mathrm{BHI}$ broth and rocket surface, respectively.
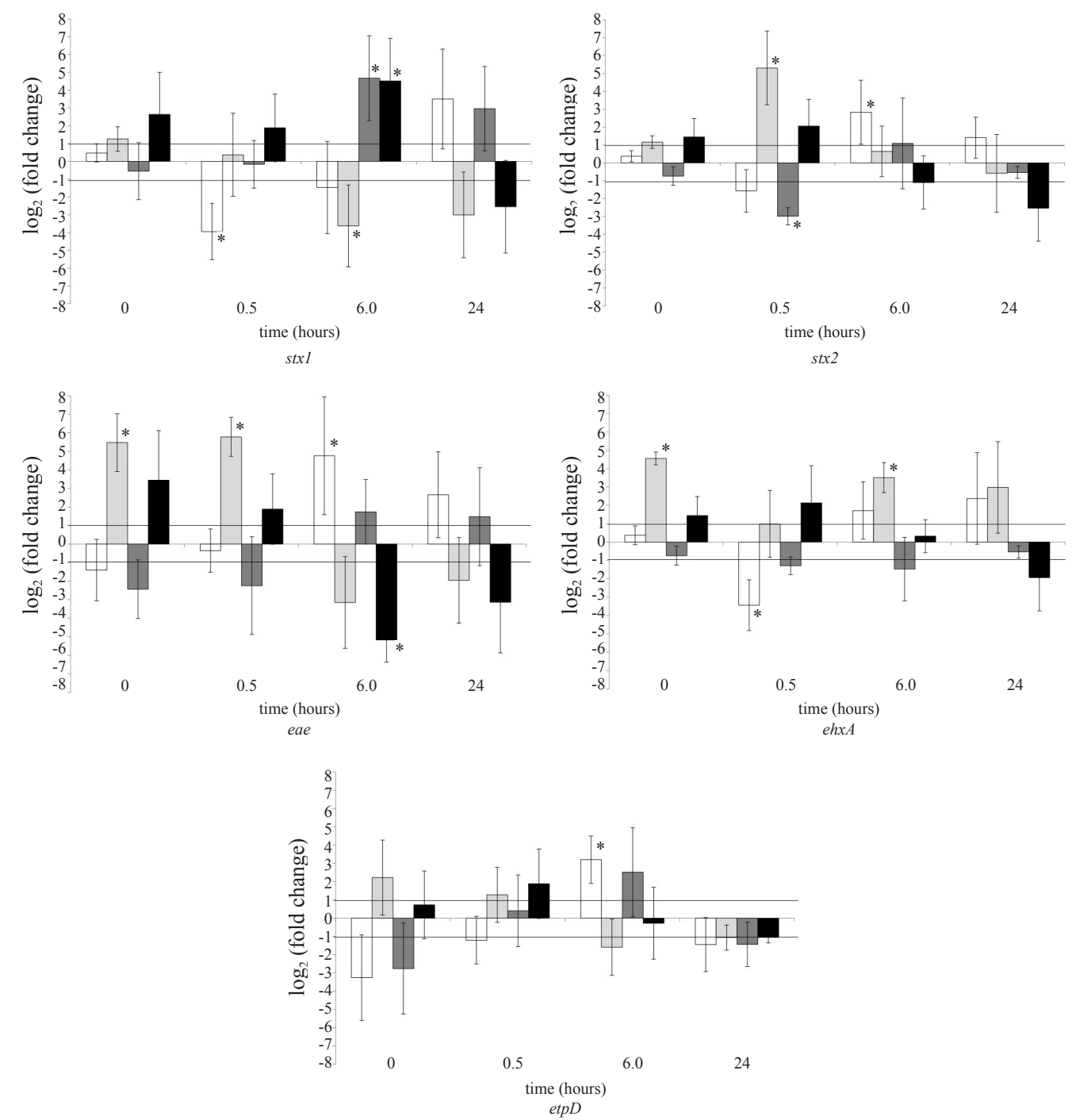

Figure 1. Effect of substrate type and temperature on the relative transcription of $s t x 1$, stx 2 , eae, ehx $A$ and etpD during growth of Escherichia coli $0157: \mathrm{H} 7$ strain $\mathrm{LQC} 15263$ in $\mathrm{BHI}$ broth and on rocket at 4 and $10^{\circ} \mathrm{C}$. Relative transcription of the genes under study is presented as follows: if visible, white bars, transcription levels during growth at $4^{\circ} \mathrm{C}$ on rocket compared to the transcription levels during growth at $4^{\circ} \mathrm{C}$ in $\mathrm{BHI}$ broth; light grey bars, transcription levels during growth at $10^{\circ} \mathrm{C}$ on rocket compared to the transcription levels during growth at $10^{\circ} \mathrm{C}$ in $\mathrm{BHI}$ broth; dark grey bars, transcription levels during growth at $10^{\circ} \mathrm{C}$ on $\mathrm{BHI}$ broth compared to the transcription levels during growth at $4^{\circ} \mathrm{C}$ in $\mathrm{BHI}$ broth; and black bars, transcription levels during growth at $10^{\circ} \mathrm{C}$ on rocket compared to the transcription levels during growth at $4^{\circ} \mathrm{C}$ on rocket. Error bars represent the standard deviation of the mean value. The asterisk indicates that transcription is significantly $(p<0.05)$ above or below the values of 1 and -1 , respectively, that were used as threshold

Assessment of gene transcription under various food-related conditions offers improved understanding of the physiology of the microorganism and the responses upon exposure to food-related stresses. Under this perspective, several studies have been performed.

stx 1 and stx 2 consist of two subunits each, designated A and B, and encode the production of two types of Shiga toxins. Their structure and function have been extensively studied and comprehensively reviewed by Melton-Celsa et al. ${ }^{[28]}$. eae is located on the locus of enterocyte effacement (LEE) and encodes for intimin, a protein that is necessary for the intimate contact between the pathogen and the host cell. eh $x A$ is a part of the hemolysin operon (ehxCABD) located on pO157; it is the structural gene of the hemolysin while $e h x B$ and $e h x D$ encode the specific secretion machinery and 
ehxC the necessary modifying factor ${ }^{[29]}$. etpD is a part of the etp gene cluster that is located on the pO157 plasmid of EHEC O157:H7 ${ }^{[30,31]}$. This gene cluster encodes for a type II secretion system through which StcE, an extracellular zinc metalloprotease, is secreted. StcE has been characterized as a potential virulence factor due to the cleavage of $\mathrm{C} 1$ esterase inhibitor as well as gp340 and MUC7, two salivary glucoproteins, contributing thus to intimate adherence of the pathogen to the HEp-2 cell surface ${ }^{[32]}$. All these genes, but mostly stx 1, stx 2 and eae, have been extensively used as an indicator of virulence potential of isolates ${ }^{[33-37]}$.

In the present study, growth on the rocket surface resulted in downreguation of stx 1 and upregulation of stx2 and eae at both temperatures, downregulation of $e h x A$ at $4^{\circ} \mathrm{C}$, as well as upregulation of $e t p D$ and $e h x A$ at 4 and $10^{\circ} \mathrm{C}$. In addition, growth at $10^{\circ} \mathrm{C}$ resulted in upregulation of stx 1 and downregulation of stx2 and eae. However, these observations were not consistent throughout all sampling times.

The transcriptomic response of these genes to a variety of challenges has been assessed to some extent. Rashid et al. ${ }^{[38]}$ studied the transcription of stx2 and ehxA from fecal samples derived from naturally infected humans and experimentally infected calves and reported that these genes were not differentially transcribed. Bergholz et al. ${ }^{[39]}$ reported downregulation of eae at early stationary stage during growth in MOPS minimal media at $37^{\circ} \mathrm{C}$ but no differential transcription of stxlA, stx $1 B$, stx $2 A$ and $s t x 2 B$. These results oppose the ones presented in the current study. More accurately, upregulation of eae was observed during growth on rocket surface, which may be considered as less nutritious than BHI broth. Moreover, stx 1 was downregulated and $s t x 2$ was upregulated. Olesen and Jespersen ${ }^{[23]}$ reported that long term adaptation to conditions representing acidity and salinity of 3 EHEC strains did not change significantly the relative transcription levels of eae, concurring with the studies of Allen et al. ${ }^{[40]}$ and Bergholz et al. ${ }^{[4]}$. In the first case acid shock (pH 3.5) had no effect on the transcription levels of eae while in the second a model apple juice system was employed to apply the same acid shock. On the contrary, transcription levels of stx $1 A$ and $s t x 2 A$ were affected but in a strain-dependent manner. More accurately, only strain EDL933 exhibited induction of stx $1 A$ relative transcription after long term salt stress. On the contrary, stx $2 A$ was upregulated after long term adaptation to salt and acid stresses applied individually in EDL933 strain but downregulated in STEC2 and c196-01 strains ${ }^{[23]}$. Saitoh et al. ${ }^{[29]}$ reported that Ehx levels increased with the overexpression of GrlA, indicating that GrlA is responsible for $e h x A$ regulation. Carey et al. ${ }^{[11]}$ assessed the transcription of stx $1 A$, stx $2 A$ and eae during growth on romaine lettuce incubated at 4 and $15^{\circ} \mathrm{C}$ for up to 9 days in aerobic conditions while Sharma et al. ${ }^{[12]} e a e, e h x A$ and $s t x 2$ during growth on shredded lettuce stored at 4 and $15^{\circ} \mathrm{C}$ under modified atmospheres. In both studies upregulation was reported as an effect of storage time in both cases and storage under near atmospheric conditions in the latter case. However, direct comparison with the results obtained in the present study is not possible due to the different quantification strategies. Upregulation of $s t x 1 A$ was reported by King et al. ${ }^{[42]}$ as a result of exposure to $\mathrm{HCl}$ at $\mathrm{pH}$ 5.5. Increase of Stx 2 production by two E. coli $\mathrm{O} 157: \mathrm{H} 7$ strains grown in Luria-Bertani broth supplemented with $2 \%$ $\mathrm{NaCl}$ was reported by Harris et al. ${ }^{[43]}$. In the same study addition of $3 \% \mathrm{NaCl}$ resulted in the decrease of Stx 2 production. Downregulation of stx $1 \mathrm{~A}$ and $s t x 2 \mathrm{~A}$ on the $7^{\text {th }}$ day of growth on ground beef stored at $4^{\circ} \mathrm{C}$ was reported by Mahmoudzadeh et al. ${ }^{[13]}$. Similarly, downregulation of eae was reported under sublethal lactoperoxidase stress ${ }^{[44]}$, concurring with the results presented by Huang et al. ${ }^{[45]}$, which demonstrated repression of eae and $s t x$ genes expression through proteomic analysis. On the contrary, upregulation of eae was reported by Slanec and Schnidt ${ }^{[46]}$ and Kocharunchitt et al. ${ }^{[4]]}$. In the first case the upregulation was detected after heat treatment of inoculated ground beef at $48^{\circ} \mathrm{C}$ for $10 \mathrm{~min}$ but not after heat treatment at $37^{\circ} \mathrm{C}$ for $10 \mathrm{~min}$. In the latter study, the upregulation was reported $80 \mathrm{~min}$ after an abrupt downshift in water activity obtained by $\mathrm{NaCl}$ in $\mathrm{BHI}$ broth. Landstorfer et al. ${ }^{[48]}$ assessed eae, $\operatorname{stx} 1 A$, stx $1 B$, stx $2 A$ and $\operatorname{stx} 2 B$ transcription after growth in a series of different growth conditions. Downregulation of eae was reported after growth in ten-fold diluted lysogeny broth at $\mathrm{pH} 4$ or $\mathrm{pH} 9$, with the addition of $200 \mathrm{mg} / \mathrm{L}$ sodium nitrite, during growth at 15 or $37^{\circ} \mathrm{C}$, on the solidified medium, as well as spinach juice, radish sprouts and cattle feces. Downregulation was also reported regarding stx $2 A$ after growth in spinach juice and cattle feces. Regarding $\operatorname{stx} l A$ and $\operatorname{stx} l B$, upregulation was detected after growth in lysogeny broth at $\mathrm{pH} 9.0$, the solidified medium, the minimal medium but downregulation on radish sprouts. Finally, stx $2 B$ was not regulated under any growth condition assessed. Heat shock $\left(47.5^{\circ} \mathrm{C}\right.$ for $\left.10 \mathrm{~min}\right)$ of $E$. coli $\mathrm{O} 157: \mathrm{H} 7$ in dairy compost resulted in upregulation of stxl but downregulation of $s t x 2$ and $e a e^{[49]}$. Similarly, transient cold shock in romaine lettuce leaf lysate resulted in upregulation of stxl but downregulation of eae ${ }^{[50]}$. However, eae was not differentially regulated during preharvest survival on butterhead lettuce ${ }^{[14]}$ concurring with the results presented by Xicohtencatl-Cortez et al. ${ }^{[51]}$ who reported that this gene was not involved in attachment to fresh produce. Again, no direct comparison can take place with the results obtained in the present study due to different quantification strategies. Regarding etpD regulation, it has not been previously assessed during growth of $E$. coli $\mathrm{O} 157: \mathrm{H} 7$ in any food-related substrate, at least as far as the authors were concerned. 


\section{Conclusion}

The differential transcription of E. coli $\mathrm{O} 157: \mathrm{H} 7$ key virulence genes during growth on rocket surface was successfully assessed for the first time. The effect of growth substrate, temperature and time on the transcription of the genes under study can be summarized into the downregulation of stxl and ehxA during growth on rocket surface at $4^{\circ} \mathrm{C}$, upregulation of stx 2 and eae during growth on rocket surface at both 4 and $10^{\circ} \mathrm{C}$ and the upregulation of etpD and ehxA during growth on rocket surface at 4 and $10^{\circ} \mathrm{C}$, respectively. In addition, increase of incubation temperature, i.e. from 4 to $10^{\circ} \mathrm{C}$ resulted in upregulation of stx 1 and downregulation of stx 2 and eae. Although the above trends were detected, further research is still necessary in order to improve our understanding of the physiology of this foodborne pathogen and the responses during exposure to food-related stimuli.

\section{References}

[1] Hadjilouka A, Paramithiotis S, Drosinos EH. Prevalence of Escherichia coli and outbreaks from ready to eat fresh fruits and vegetables. In: Coliforms: Occurrence, Detection Methods and Environmental Impact. G. McCoy. (ed). Nova Publishers; 2015; 71-106.

[2] Centers for Disease Control and Prevention (CDC). Surveillance for Foodborne Disease Outbreaks, United States, 2012, Annual Report. Atlanta, Georgia: US Department of Health and Human Services, CDC; 2014b.

[3] Centers for Disease Control and Prevention (CDC). Surveillance for Foodborne Disease Outbreaks, United States, 2014, Annual Report. Atlanta, Georgia: US Department of Health and Human Services, CDC; 2016.

[4] Centers for Disease Control and Prevention (CDC). Surveillance for Foodborne Disease Outbreaks, United States, 2013, Annual Report. Atlanta, Georgia: US Department of Health and Human Services, CDC; 2015.

[5] Centers for Disease Control and Prevention (CDC). Surveillance for Foodborne Disease Outbreaks, United States, 2011, Annual Report. Atlanta, Georgia: US Department of Health and Human Services, CDC; 2014a.

[6] Centers for Disease Control and Prevention. Ongoing multistate outbreak of Escherichia coli serotype O157:H7 infections associated with consumption of fresh spinach-United States. 2006. Available from: http://www.cdc.gov/mmwr/ preview/mmwrhtml/mm5538a4.htm [Accessed 26th July 2013].

[7] Ministry of Health and Welfare of Japan. National Institute of Infectious Diseases and Infectious Disease Control Division. Verocytotoxin-producing Escherichia coli (enterohemorrhagic E. coli) infection, Japan, 1996-June 1997. Infectious Agents Surveillance Report. 1997; 18: 153-154.

[8] Castro VS, Carvalho RCT, Conte-Junior CA, Figuiredo EES. Shiga-toxin producing Escherichia coli: pathogenicity, supershedding, diagnostic methods, occurrence, and foodborne outbreaks. Comprehensive Reviews in Food Science and Food Safety. 2017; 16: 1269-1279.

[9] Bhunia AK. Foodborne microbial pathogens. Mechanisms and Pathogenesis. Springer; 2008.

[10] Mellies JL, Barron AMS, Carmona AM. Enteropathogenic and enterohemorrhagic Escherichia coli virulence gene regulation. Infection and Immunity. 2007; 75: 4199-4210.

[11] Carey CM, Kostrzynska M, Thompson S. Escherichia coli O157:H7 stress and virulence gene expression on Romaine lettuce using comparative real-time PCR. Journal of Microbiological Methods. 2009; 77: 235-242.

[12] Sharma M, Lakshman S, Ferguson S, Ingram DT, Luo Y, Patel J. Effect of modified atmosphere packaging on the persistence and expression of virulence factors of Escherichia coli O157:H7 on shredded iceberg lettuce. Journal of Food Protection. 2011; 74: 718-726.

[13] Mahmoudzadeh M, Hosseini H, Hedayati M, Khanghah AM, Chaves RD, Azizkhani M. Establishment of a method for describing stx genes expression of E. coli $\mathrm{O} 157: \mathrm{H} 7$ in ground beef matrix during refrigerated storage. Journal of Food Safety. 2016; 36: 220-226.

[14] Van der Linden I, Cottyn B, Uyttendaele M, Vlaemynck G, Heyndrickx M, Maes M, Holden N. Microarray-based screening of differentially expressed genes of $E$. coli O157:H7 Sakai during preharvest survival on butterhead lettuce. Agriculture. 2016; 6: 6.

[15] Barillari J, Canistro ME, Paolini M, Ferroni F, Pedulli GF, Iori R, Valmigli L. Direct antioxidant activity of purified glucoerucin, the dietary secondary metabolite contained in rocket (Eruca sativa Mill.) seeds and sprouts. Journal of Agricultural and Food Chemistry. 2005; 53: 2475-2482.

[16] Koukounaras A, Siomos AS, Sfakiotakis E. 1-Methylcyclopropene prevents ethylene induced yellowing of rocket leaves. Postharvest Biology and Technology. 2006; 41: 109-111.

[17] Koukounaras A, Siomos AS, Sfakiotakis E. Postharvest $\mathrm{CO}_{2}$ and ethylene production and quality of rocket (Eruca sativa Mill.) leaves as affected by leaf age and storage temperature. Postharvest Biology and Technology. 2007; 46: 
$167-173$.

[18] Koukounaras A, Siomos AS, Sfakiotakis E. Impact of heat treatment on ethylene production and yellowing of modified atmosphere packaged rocket leaves. Postharvest Biology and Technology. 2009; 54: 172-176.

[19] Melchini A, Costa C, Traka M, Miceli N, Mithen R, De Pasuqale R, Trovato A. Erucin, a new promising cancer chemiopreventive agent from rocket salads, shows anti-proliferative activity on human lung carcinoma A549 cells. Food and Chemical Toxicology. 2009; 47: 1430-1436.

[20] Amodio ML, Derossi A, Mastrandrea L, Colelli G. A study of the estimated shelf life of fresh rocket using a non-linear model. Journal of Food Engineering. 2015; 150: 19-28.

[21] Cavaiuolo M, Cocetta G, Bulgari R, Spinardi A, Ferrante A. Identification of innovative potential quality markers in rocket and melon fresh-cut produce. Food Chemistry. 2015; 188: 225-233.

[22] Olson KE, Dolan GF, Muller UF. In vivo evolution of a catalytic RNA couples trans-splicing to translation. PLoS ONE. 2014; 9: e86473.

[23] Olesen I, Jespersen L. Relative gene transcription and pathogenicity of enterohemorrhagic Escherichia coli after longterm adaptation to acid and salt stress. International Journal of Food Microbiology. 2010; 141: 248-253.

[24] Zhou K, Zhou L, Lim QE, Zou R, Stephanopoulos G, Too HP. Novel reference genes for quantifying transcriptional responses of Escherichia coli to protein overexpression by quantitative PCR. BMC Molecular Biology. 2011; 12: 18.

[25] Letoffe S, Chalabaev S, Dugay J, Stressmann F, Audrain B, Portais JC, Letisse F, Ghigo JM. Biofilm microenvironment induces a widespread adaptive amino-acid fermentation pathway conferring strong fitness advantage in Escherichia coli. PLoS Genetics. 2017; 13: e1006800.

[26] Nielsen EM, Andersen MT. Detection and characterization of verotoxin-producing Escherichia coli by automated 5' nuclease PCR assay. Journal of Clinical Microbiology. 2003; 41: 2884-2893.

[27] Hadjilouka A, Molfeta C, Panagiotopoulou O, Paramithiotis S, Mataragas M, Drosinos EH. Expression of Listeria monocytogenes key virulence genes during growth in liquid medium, on rocket and melon at 4,10 and $30^{\circ} \mathrm{C}$. Food Microbiology. 2016; 55: 7-15.

[28] Melton-Celsa AR. Shiga toxin (Stx) classification, structure, and function. Microbiol Spectrum. 2014; 2(3): EHEC0024-2013.

[29] Saitoh T, Iyoda S, Yamamoto S, Lu Y, Shimuta K, Ohnishi M, Terajima J, Watanabe H. Transcription of the ehx enterohemolysin gene is positively regulated by GrlA, a global regulator encoded within the locus of enterocyte effacement in enterohemorrhagic Escherichia coli. Journal of Bacteriology. 2008; 190: 4822-4830.

[30] Schmidt H, Henkel B, Karch H. A gene cluster closely related to type II secretion pathway operons of Gram-negative bacteria is located on the large plasmid of enterohemorrhagic Escherichia coli 0157 strains. FEMS Microbiology Letters. 1997; 148: 265-272.

[31] Lim JY, Yoon JW, Hovde CJ. A brief overview of Escherichia coli O157:H7 and its plasmid O157. Journal of Microbiology and Biotechnology. 2010; 20: 5-14.

[32] Grys TE, Siegel MB, Lathem WW, Welch RA. The StcE protease contributes to intimate adherence of enterohemorrhagic Escherichia coli O157:H7 to Host Cells. Infection and Immunity. 2005; 73: 1295-1303.

[33] Bielaszewska M, Sonntag A-KK, Schmidt MA, Karch H. Presence of virulence and fitness gene modules of enterohemorrhagic Escherichia coli in atypical enteropathogenic Escherichia coli O26. Microbes and Infection. 2007; 9: 891897.

[34] Cha W, Fratamico PM, Ruth LE, Bowman AS, Nolting JM, Manning SD, Funk JA. Prevalence and characteristics of Shiga toxin-producing Escherichia coli in finishing pigs: Implications on public health. International Journal of Food Microbiology. 2018; 264: 8-15.

[35] Son I, Binet R, Lin A, Hammack TS, Kase JA. Identification of five Shiga toxin-producing Escherichia coli genes by Luminex microbead-based suspension array. Journal of Microbiological Methods. 2015; 111: 108-110.

[36] Malik A, Nagy B, Kugler R, Szmolka A. Pathogenic potential and virulence genotypes of intestinal and faecal isolates of porcine post-weaning enteropathogenic Escherichia coli. Research in Veterinary Science. 2017; 115: 102-108.

[37] Fierz L, Cernela N, Hauser E, Nuesch-Inderbinen M, Stephan R. Characteristics of Shiga toxin-producing Escherichia coli strains isolated during 2010-2014 from human infections in Switzerland. Frontiers in Microbiology. 2017; 8: 1471.

[38] Rashid RA, Tabata TA, Oatley MJ, Besser TE, Tarr PI, Moseley SL. Expression of putative virulence factors of Escherichia coli $\mathrm{O} 157: \mathrm{H} 7$ differs in bovine and human infections. Infection and Immunity. 2006; 74: 4142-4148.

[39] Bergholz TM, Wick LM, Qi W, Riordan JT, Ouellette LM, Whittam TS. Global transcriptional response of Escherichia coli $\mathrm{O} 157: \mathrm{H} 7$ to growth transitions in glucose minimal medium. BMC Microbiology. 2007; 7: 97.

[40] Allen KJ, Lepp D, McKellar RC, Griffiths MW. Examination of stress and virulence gene expression in Escherichia coli O157:H7 using targeted microarray analysis. Foodborne Pathogens and Disease. 2008; 5: 437-447.

[41] Bergholz TM, Vanaja SK, Whittam TS. Gene expression induced in Escherichia coli O157:H7 upon exposure to mod- 
el apple juice. Applied and Environmental Microbiology. 2009; 75: 3542-3553.

[42] King T, Lucchini S, Hinton JCD, Gobius K. Transcriptomic analysis of Escherichia coli O157:H7 and K-12 cultures exposed to inorganic and organic acids in stationary phase reveals acidulant- and strain-specific acid tolerance responses. Applied and Environmental Microbiology. 2010; 76: 6514-6528.

[43] Harris SM, Yue W-F, Olsen SA, Hu J, Means WJ, McCormick RJ, Du M, Zhu M-J. Salt at concentrations relevant to meat processing enhances Shiga toxin 2 production in Escherichia coli O157:H7. International Journal of Food Microbiology. 2012; 159: 186-192.

[44] Parry-Hanson AA, Jooste PJ, Buys EM. Relative gene expression in acid-adapted Escherichia coli O157:H7 during lactoperoxidase and lactic acid challenge in Tryptone Soy Broth. Microbiological Research. 2010; 165: 546-556.

[45] Huang Y-J, TsaiT-Y, PanT-M. Physiological response and protein expression under acid stress of Escherichia coli O157:H7 TWC01 isolated from Taiwan. Journal of Agricultural and Food Chemistry. 2007; 17: 7182-7191.

[46] Slanec T, Schmidt H. Specific expression of adherence-related genes in Escherichia coli O157:H7 strain EDL933 after heat treatment in ground beef. Journal of Food Protection. 2011; 74: 1434-1440.

[47] Kocharunchitt C, King T, Gobius K, Bowman JP, Ross T. Global genome response of Escherichia coli O157:H7 Sakai during dynamic changes in growth kinetics induced by an abrupt downshift in water activity. PLoS ONE. 2014; 9(3): e90422.

[48] Landstorfer R, Simon S, Schober S, Keim D, Scherer S, Neuhaus K. Comparison of strand-specific transcriptomes of enterohemorrhagic Escherichia coli O157:H7 EDL933 (EHEC) under eleven different environmental conditions including radish sprouts and cattle feces. BMC Genomics. 2014; 15: 353.

[49] Singh R, Jiang X. Expression of stress and virulence genes in Escherichia coli O157:H7 heat shocked in fresh dairy compost. Journal of Food Protection. 2015; 78: 31-41.

[50] Kennedy NM, Mukherjee N, Banerjee P. Escherichia coli O157:H7 cells exposed to lettuce leaf lysate in refrigerated conditions exhibit differential expression of selected virulence and adhesion-related genes with altered mammalian cell adherence. Journal of Food Protection. 2016; 79: 1259-1265.

[51] Xicohtencatl-Cortes J, Chacon ES, Saldana Z, Freer E, Giron JA. Interaction of Escherichia coli O157:H7 with leafy green produce. Journal of Food Protection. 2009; 72: 1531-1537. 